\title{
THE SPECTRUM OF MYOPATHIES IN THE CITY OF SÃO PAULO
}

\author{
JosÉ A. LEVY * \\ ABRAM TOPCZEWSKI * \\ Lucia Iracema Z. de Mendonça * \\ MAYANA ZaTZ * \\ RUTH BLAY LEVISKY *
}

Having studied muscular diseases for the past 15 years at the Neurologic Clinic of the Medical School of the University of São Paulo, we started a "study group", composed of neurologist, electromyographists, pathologists, geneticists and biochemists, and created an out-patient clinic specially for the treatment of these patients. Reviewing the studied cases we found a total number of 466 patients (Table 1). However, the cases of myatenia were not studied in depth, since this was done by Prof. José Lamartine de Assis.

\begin{tabular}{lrr}
\hline \multicolumn{1}{c}{ Muscular diseases } & suspect & proved \\
\hline & & 262 \\
Progressive muscular dystrophy (PMD) & 29 & 179 \\
Polymyositis & 2 & 2 \\
Central core disease & 1 & 1 \\
Benign congenital myopathy & 2 & 2 \\
Kearns syndrome & 1 & 1 \\
Isaacs syndrome & 19 & 19 \\
Myotonic dystrophy & 1 & 1 \\
Congenital myotony & 1 & 1 \\
Adynamia episodica & 1 & 1 \\
Diabetic myopathy & 145 & 145 \\
Myastenia gravis & 2 & 2 \\
Eaton Lambert syndrome & & \\
\hline
\end{tabular}

Table 1 - Suspected and proved diagnosis in the 466 cases reported.

We do not intend to discuss whether some of the types of diseases reported in this paper are actually and truly cases of myopathies, since at

* Center of Neurologic Investigations, Neurological Clinic of the Medical School of the University of São Paulo (Prof. Horacio M. Canelas). 
this stage of events - and due to the daily progress made chiefly through histochemical and electronic microscopic studies - there is much confusion on the subject (King Engel, 1971) ${ }^{3}$.

We have also left out of this review the cases of periodical paralysis and those of myopathies of endocrin origin, since these cases are referred to other specialists. On the other hand, it was impossible to arrive at a precise diagnosis in a large number of the patients because, at the time when they were examined, we did not have the equipment needed for some

\begin{tabular}{lrrr}
\hline \multicolumn{1}{c}{ Diagnostic } & Total number of cases & With confirmed diagnosis \\
\hline PMD & 212 & $179(79 \%)$ \\
Polymyositis & 29 & $19(8 \%)$ \\
Myotonic dystrophy & 19 & $19(8 \%)$ \\
Other & 9 & $9(3 \%)$ \\
Total & 319 & 226 & \\
\end{tabular}

Table 2 - Cases of myopathies.

Form of disease Total number of cases With confirmed diagnosis

\begin{tabular}{lrr} 
& & \\
Duchenne & 147 & $111(62 \%)$ \\
Becker & 21 & $18(10 \%)$ \\
Limb girdle & 75 & $39(21 \%)$ \\
Facioscapulohumeral & 14 & $8(4 \%)$ \\
Congenital & 4 & $2(1 \%)$ \\
Oculopharingeal & 1 & $1(0,5 \%)$ \\
Total & 262 & 179 \\
\hline
\end{tabular}

Table 3 - Progressive muscular dystrophy.

\begin{tabular}{lrcc}
\hline \multicolumn{1}{c}{ Type } & Cases & Ventricular overload & Other alterations \\
\hline Duchenne & 33 & 30 & 2 \\
Becker & 7 & 4 & 2 \\
Limb girdle & 12 & 2 & \\
\hline
\end{tabular}

Table 4 - Electrocardiographic examinations. 
of the tests which are considered essential in the diagnosis and also because many of the patients did not return for other consultations.

The criterion used in the diagnosis was clinic, genetic, ełectromyographic, biochemical (CPK, GOT, GPT, LDH), histopathological and electrocardiographic.

\section{CASUISTIC}

As can be verified in table 2, excluding the cases of myastenia and Eaton Lambert syndrome, we have 226 cases $(70 \%)$ with a confirmed diagnosis and 93 cases $(30 \%)$ with a probable diagnosis, with a total of 319 cases. Among the cases with confirmed diagnosis we have 179 cases $(79 \%)$ of progressive muscular dystrophies (PMD); 19 cases $(8 \%)$ of polymiositis; 19 cases $(8 \%)$ of myotonic dystrophy; and 9 cases $(3 \%)$ of other disorders.

In comparing the numbers of table 2 we can see that for those cases not t:oughly studied the diagnosis is highly probable. This is also verified in relation to our study of several forms of PMD (Table 3), where we find 179 confirmed and 83 probable diagnosis with a total of 262 cases, the former being thus distributed: 111 cases of Duchenne $(62 \%) ; 18$ cases of Becker $(10 \%) ; 39$ cases of limb girdle $(21 \%) ; 8$ cases of facioscapulohumeral $(4 \%) ; 2$ cases of congenital $(1 \%) ;$ and 1 case of oculopharingeal $(0,5 \%)$.

In the cases with a confirmed diagnosis of PMD nothing important was shown in the enzymatic activity, but the ract that the CPK was increased in all the cases; this was not the case with the GOT, GPT and LDH. The electrocardiographic studies (Table 4), however, showed very interesting results, since a ventricular overload was found in 30 out of 33 cases of Duchenne $(90 \%)$ and also because in only one of these cases the test resulted normal (3\%). A ventricular overload was found in 4 of the 7 cases of Becker $(57 \%)$, whereas in the other forms the tests usually resulted normal. Electrencephalography resulted normal in 28 out of the 31 cases studied $(90 \%)$.

As to the familial character part, it was present in 60 out of the 111 cases of Duchenne; in 15 of the 18 cases of Becker; in 18 of the 39 cases of limb girdle; in 6 of the 8 cases of fascioscapulohumeral; in the one case of oculopharingeal; and in none of the congenital cases.

Among the cases of Duchenne, six patients were of female sex; and of these six cases, in three there were manifestations of this disorder in heterozygous patients (two mothers and one sister, carriers of the gene) and this could be explained by Lyon's theory. The other three seem to be Duchenne cases with an autossomic character.

Electromyography results were compatible with PMD in all of the confirmed cases; as for the muscle biopsy, the results were compatible with PMD in 62 out of 64 cases of Duchenne $(96 \%)$; in all the cases of limb girdle, fascioscapulohumeral, congenital and oculopharingeal $(100 \%)$.

In the cases of polymyositis the muscle biopsy results were compatible with this disorder in 14 cases out of $19(83 \%)$; in three of them the biopsy was typical of PMD and in two cases it was normal. As for the electromyography, the results suggested polymyositis in half of the cases; the other half were typical of PMD.

Genetic Counselling - In order to organize the Genetic Counselling Service (GC) we made a detailed survey of the patients' families, dealing with the following 
aspects: a) confirmation or establishing of diagnosis; b) survey of heredogram in as comprehensive a way as possible; $c$ ) use of the test made for measurement of CPK enzyme activity in the blood serum for defining diagnosis of the affected person, as well as for detecting healthy carriers of the gene of the Duchenne and Becker types of PMD; $d$ ) definition of types of heredity found in the anomaly; e) estimate of the affection's recurrence risks; $f$ ) orientation of families through Genetic Counselling itself.

Murphy et al. $(1966)^{5}$, Emery and Morton $(1968)^{2}$, Emery et al. (1967) ${ }^{1}$, Murphy and Mutalik $(1969)^{\circ}$, Levisky $(1973)^{4}$; and Zatz 1973) ${ }^{7}$, have reported on the importance of a statistical method for estimating the total risks of a woman being the carrier of a X-linked gene. Besides taking into consideration the consultant's position in the genealogy, such a method utilizes results of the test of detection of carriers by means of biochemical dosage of CPK. It is known that one third of evident heterozygotes will show normal results, whereas only $5 \%$ of normal women with no record of Duchenne type PMD in the family will show an increased CPK rate.

A combination is made, of these different types of data, through the Bayes method, for evaluating the probabilities of a woman being the carrier of the PMD gene (Levisky, 1973)4.

CPK dosages were done in our laboratory for all patients affected by the different forms of PMD, and also for many of their relatives, specially mothers and sisters of patients suffering from PMD (Zatz, 1973) ${ }^{7}$. The method chosen for dosage of CPK in the blood serum is described in Bulletin 520-80/F, published by Sigma Chemical Company (1967), and allows for the discrimination of the following scale of values: normal: 0 to 12 Sigma Units (US) per $\mathrm{ml}$. of serum; borderline: 12 to 20 US per $\mathrm{ml}$. of serum; increased: over $20 \mathrm{US}$ per $\mathrm{ml}$. of serum.

Arround 160 families of patients affected by the various types of PMD received orientation as to GC.

In 1970, five adolescent heterozygotes between 12 and 18 years of age, who had an increased CPK dosage (characteristic of female carriers), received psychological help before they faced GC.

\section{DISCUSSION}

The evidence of 466 cases of myopathies, in a total of almost 100.000 out-patients of the Neurological Department of the Medical School of the University of São Paulo constitutes in itself data to demonstrate the importance of these affections.

According to all authors, PMD was the most frequently found myopathy in this research-work, the second being myasthenia gravis. The low number of polymyositis cases can be explained by the fact that attention to this affection was only called, in our milieu, in the last ten years.

Among the complementary tests, stress should be given to electrocardiographs, which were abnormal in 32 out of the 33 cases of the Duchenne form of PMD, and to the CPK, which was increased in all confirmed cases of PMD.

Furthermore, genetic counselling service should be emphatized in the case of an affection such as this, for which no treatment has yet been found. 


\section{SUMMARY}

A review of all myopathic patients treated at the Neurologic Clinic of the Medical School of the University of São Paulo during the past 15 years is reported. A total of 466 cases were examined and distributed as follows: $56 \%$ of progressive muscular dystrophy; $31 \%$ of myasthenia gravis; $6 \%$ of polymyositis; $4 \%$ of myotonic dystrophy; and the remainder of several different diseases (central core disease, Kearns-syndrome, myotonia congenita, adynamia episodica hereditaria, diabetic myopathy and Eaton-Lambert syndrome). Enzymatic dosages, electromyography, muscle biopsy, electrocardiography and genetic counselling are also reported.

\section{RESUMO}

Os autores fazem uma revisão de todos os casos de miopatias tratados na Clínica Neurológica da F.M.U.S.P. durante os últimos 15 anos. Foram examinados 466 casos, assim distribuidos: $56 \%$ de distrofia muscular progressiva; $31 \%$ de miastenia grave; $6 \%$ de polimiosite; $4 \%$ de distrofia miotônica e, o restante, de várias outras moléstias (Central core disease, sindrome de Kearns, miotonia congênita, adinamia episódica hereditária, miopatia diabética e sindrome de Eaton-Lambert). São relatadas também as dosagens enzimáticas, eletromiografia, biópsia muscular, eletrocardiografia e aconselhamento genético.

\section{REFERENCES}

1. EMERY, A.E.H.; WILKINSON, E. \& MURPHY, E.A. - Genetic counselling in. Duchenne muscular dystrophy. Proceedings $2^{\text {nd }}$ International Congress of NeuroOphthalmology, Montreal, 1967. Excerpta Medica Foundation, Amsterdam, 1969. v. 1 , p. 106 .

2. EMERY, A.E.H. \& MORTON, R. - Genetic counselling in lethal X-linked disorders. Acta Genet. Stat. Med. (Basel) 18:534, 1968.

3. KING ENGEL, Z.W. - Classification of neuromuscular disorders. In Daniel Bergsma - The Clinical Delineation of Birth Defects. Williams and Wilkins, Baltimore, 1971, pp. 18.

4. LEVISKY, R.B. - Estudo genético e aconselhamento em distrofias musculares progressivas. Tese de doutoramento, Departamento de Biologia, Instituto de Biociências da USP, São Paulo, 1973.

5. MURPHY, E.A.; MUTALIK, G.S. \& ELRIGE, R. - The application of Bayesian methods in genetic counselling. Proceedings $3^{\text {rd }}$ International Congress of Human Genetics. Chicago, 1966.

6. MURPHY, E.A. \& MUTALIK, G.S. - The application of Bayesian methods in genetic counselling. Hum. Hered. 19:126, 1969.

7. ZATZ, M, - Atividade da creatinina-fosfoquinase (CPK) e estudos de ligação em distrofias musculares progressivas de herança ligada ao $X$. Tese de doutoramento, Departamento de Biologia, Instituto de Biociências da USP, São Paulo, 1973 . 